\title{
A replacement name for Gehyra punctulata Doughty, Bauer, Pepper \& Keogh, 2018 (Reptilia: Squamata: Gekkonidae) and the nomenclatural status of Phyria punctulata Gray, 1842
}

\author{
Ryan J. Ellis ${ }^{1,}{ }^{*}$, Paul Doughty ${ }^{1}$, Aaron M. Bauer ${ }^{2}$, Mitzy Pepper ${ }^{3}$ and J. Scott Keogh ${ }^{3}$ \\ 1 Department of Terrestrial Zoology, Western Australian Museum, Locked Bag 49, Welshpool DC, \\ Western Australia 6986, Australia. \\ 2 Department of Biology, Villanova University, 800 Lancaster Ave, Villanova, Pennsylvania 19085, U.S.A. \\ ${ }^{3}$ Division of Evolution, Ecology \& Genetics, Australian National University, Canberra, ACT 0200, \\ Australia. \\ * Corresponding author: ryan.ellis@museum.wa.gov.au
}

\begin{abstract}
KEYWORDS: Gehyra finipunctata nom. nov., Gehyra australis, nomenclature, ICZN, homonym, nomen
\end{abstract} novum, nomen dubium.

urn:Isid:zoobank.org:pub:2C018069-1D99-48FF-8311-4975BB9E57B8

In the recent revision of the Gehyra punctata (Fry, 1914) species complex, Doughty et al. (2018a, published 25 July) proposed the name Gehyra punctulata for a newly described species therein from the Pilbara region of Western Australia, Australia with the type locality of 'Mount Minnie' (p. 19). However, the name Gehyra punctulata is a junior secondary homonym of Phyria punctulata Gray, 1842 from the type locality of 'Port Essington' Northern Territory, Australia with a distribution described by Gray as 'North coast of New Holland [Australia]' (Gray 1842, p. 53). The genus Phyria Gray, 1842 is treated as a junior synonym of Gehyra Gray, 1834 (see Chrapliwy et al. 1961; Cogger et al. 1983; Bauer 1994) and the name Phyria punctulata is itself currently treated as a nomen oblitum and subjective synonym of Gehyra australis Gray, 1845 (see Chrapliwy et al. 1961; Cogger et al. 1983; Kluge 1991; Bauer 1994). However, due to the absence of an extant type specimen (presumed lost fide Boulenger 1885; Kluge 1965; Cogger et al. 1983), it is not possible to definitively allocate Phyria punctulata Gray, 1842 to any known species or populations of Gehyra Gray, 1834 and the interpretation of $P$. punctulata as a synonym of $G$. australis has been based on the limited diagnostic information and the type locality of 'Port Essington' provided by Gray (1842, p.53).

Although first described by Gray (1842), Phyria punctulata was not included by Gray (1845) in his comprehensive Catalogue of the Specimens of Lizards in the Collection of the British Museum, where the description of Gehyra australis was published. Gray (1842) noted that the majority of specimens described in his paper were 'chiefly from a collection made by Mr. Gilbert, Mr. Gould's collector, at Port Essington' (p. 54). Gray (1845), in turn, reported the origin of his specimen ' $b$.' of G. australis as 'Port Essington. From Mr. Gilbert's collection' (p. 163). This is circumstantial evidence that at least one syntype of $G$. australis is conspecific with the holotype of $P$. punctulata. Were this the case, the fact that the synonymy was not noted by Gray (1845) would not be unexpected as he sometimes substituted new names for taxa he described or carelessly described the same specimen more than once, often in different genera. However, Boulenger (1885) referred to the genus and species as incertae sedis as he was unable to locate the type specimen with the limited information provided by Gray. Chrapliwy et al. (1961) hesitantly treated $P$. punctulata as $G$. australis; however, Kluge (1965) identified some inconsistencies between Gray's description of P. punctulata and that of G. australis and treated the species as a nomen dubium, highlighting Gray's characters 'two series of diverging subdigital lamellae and ventral surfaces yellow' (Kluge 1965, p. 122) which is not typical of the Gehyra australis group which typically possesses undivided or grooved lamellae. Cogger et al. (1983) treated P. punctulata as a nomen oblitum and listed it as a synonym of $G$. australis but did not provide any reasoning for the decision. Bauer (1994) also treated $P$. punctulata as a nomen oblitum, noting that the name was tentatively referrable to and placed in synonymy with $G$. australis on the basis of type locality following Chrapliwy et al. (1961), Cogger et al. (1983) and Kluge (1991). Bauer (1994) also noted that the identify of 
P. punctulata will never be satisfactorily resolved in the absence of a type specimen.

Although P. punctulata is currently treated as a nomen oblitum and subjective synonym of $G$. australis, some characters described by Gray for the genus Phyria and $P$. punctulata are inconsistent with what is commonly referred to as $G$. australis in the Port Essington area. While the description of Phyria and P. punctulata broadly conform with the genus Gehyra, Kluge (1965) noted Gray's reference to 'two series of diverging plates beneath' the toes (Gray 1842, p. 53), presumably referring to divided subdigital lamellae, in the description of Phyria differs from $G$. australis which possesses a single series of undivided lamellae under each toe. This character is consistent with other Gehyra known to occur in the vicinity of the type locality, including G. nana Storr, 1978 and G. paranana Bourke, Doughty, Tedeschi, Oliver \& Moritz in Doughty et al. (2018b); however, these species are more prominently marked on the dorsum. With consideration that the type locality may be in error, and the locality merely reflects the port from which the specimens were shipped to the British Museum, it is possible the type of $P$. punctulata may represent a species not known to occur within the vicinity of Port Essington. Kluge (1965) also highlighted Gray's description of colouration of $P$. punctulata, 'lips, side of throat, chest, belly and underside of tail, yellow' (Gray 1942, p. 53), which differs from common colouration of G. australis in the Port Essington area; however, this may be attributed to preservation and storage of the specimen. Gray (1842), however, did mention 'olive grey, in spirits' (p. 53) and made no mention of any dorsal patterning, which is consistent with G. australis, particularly after capture and preservation and it is possible the specimen represented a more distinctly marked species such as $G$. nana or $G$. paranana and fading or loss of dorsal patterning had occurred as a result of preservation and storage in ethanol.

In the absence of a type specimen, the inability to determine with certainty to which species the name applies and limited information in the description of Phyria and Phyria punctulata by Gray (1842), we regard the name Phyria punctulata as a nomen dubium and remove it from the synonymy of $G$. australis. Despite the nomen dubium status of the name Phyria punctulata, the name punctulata is nonetheless considered unavailable for new species within the genus Gehyra in accordance with Article 59 of the Code (International Commission on Zoological Nomenclature [ICZN] 1999).

Consequently, under Articles 59-60 of the International Code of Zoological Nomenclature (the Code) (International Commission on Zoological Nomenclature [ICZN] 1999) a replacement name is required for Gehyra punctulata Doughty, Bauer, Pepper \& Keogh, 2018 because both nomina are currently referred to the genus Gehyra Gray, 1834. The name Gehyra finipunctata nom. nov. Doughty, Bauer, Pepper, Keogh \& Ellis, 2018 [ZooBank: urn:lsid:zoobank.org:act:55C1B63386BA-4FFE-B400-D151BC69AF60] is proposed as a replacement name for Gehyra punctulata Doughty, Bauer, Pepper \& Keogh, 2018. The species epithet finipunctata is derived from the Latin words finis (fine) and punctata (punctate or bearing small spots), as in bearing fine spots or finely spotted, in reference to the dorsal pattern which forms part of the species diagnosis, described by Doughty et al. (2018a) as 'background colour light reddish to greyish-brown with small dark and pale spots not in contact and evenly spaced' (pp. 19-20). The name finipunctata is an adjective formed in the nominate feminine singular.

\section{REFERENCES}

Bauer, A.M. (1994). Das Tierreich Part 109: Familia Gekkonidae (Reptilia, Sauria). Part I Australia and Oceania. Walter de Gruyter Publishers, Berlin.

Boulenger, G.A. (1885). Catalogue of the Lizards in the British Museum (Natural History) I. Gekkonidae, Eublepharidae, Uroplatidae, Pygopodidae, Agamidae. British Museum, London.

Chrapliwy, P.S., Smith, H.M. and Grant, C. (1961). Systematic status of the geckonid lizard genera Gehyra, Peropus, Hoplodactylus and Naultinus. Herpetologica 17: 5-12.

Cogger, H.G., Cameron, E.E. and Cogger, H.M. (1983). Zoological Catalogue of Australia. Vol. 1. Amphibia and Reptilia. Australian Government Publishing Service, Canberra.

Doughty, P., Bauer, A.M., Pepper, M. and Keogh, J.S. (2018a). Spots before the eyes: revision of the saxicoline geckos of the Gehyra punctata (Squamata: Gekkonidae) species complex in the Pilbara region of Western Australia. Records of the Western Australian Museum 33: 1-50. doi: 10.18195/ issn.0312-3162.33(331).2018.001-050.

Doughty, P., Bourke, G., Tedeschi, L.G., Pratt, R.C., Oliver, P.M., Palmer, R.A. and Moritz, C. (2018b). Species delimitation in the Gehyra nana (Squamata: Gekkonidae) complex: cryptic and divergent mrphological evolution in the Australian monsoonal tropics, with the description of four new species. Zootaxa 4403(2): 201-244. doi: 10.11646/zootaxa.4403.2.1.

Fry, D.B. (1914). On a collection of reptiles and batrachians from Western Australia. Records of the Western Australian Museum and Art Gallery 1: 174-210.

Gray, J.E. (1834). [Characters of two new genera of reptiles (Geoemyda and Gehyra)]. Proceedings of the Zoological Society of London 1834: 99-100.

Gray, J.E. (1842). Description of some hitherto unrecorded species of Australian reptiles and batrachians. Zoological Miscellany. Treuttel, Würtz \& Co, London, pp. 51-57.

Gray, J.E. (1845). Catalogue of the Specimens of Lizards in the Collection of the British Museum. Trustees of the British Museum/ Edward Newman, London.

International Commission on Zoological Nomenclature [ICZN]. (1999). International Code of Zoological Nomenclature. Fourth Edition. The International Trust for Zoological Nomenclature, London.

Kluge, A.G. (1965). The systematic status of certain Australian lizards of the family Gekkonidae. Australian Zoologist 13: $121-125$.

Kluge, A.G. (1991). Checklist of gekkonid lizards. Smithsonian Herpetological Information Service 85: 1-35.

Storr, G.M. (1978). Seven new gekkonid lizards from Western Australia. Records of the Western Australian Museum 6(3): 337-352.

MANUSCRIPT RECEIVED 30 JULY 2018; ACCEPTED 1 AUGUST 2018. 